\title{
Characteristics of Hydrogen Ion Transport in Urinary Bladder of Water Turtle*
}

\author{
Philip R. Steinmetz $\ddagger$ \\ (From the Departments of Medicine, Harvard Medical School and the Beth Israel Hospital, \\ Boston, Massachusetts)
}

\begin{abstract}
The mechanism of acidification by the urinary bladder of the water turtle was studied in an in vitro system which permitted control and measurement of electrical and concentration driving forces. The rate of hydrogen ion secretion was measured by means of a $\mathrm{pH}$ stat technique in the absence of exogenous carbon dioxide and bicarbonate.

Transport of hydrogen ion into the solution bathing the mucosal surface of the bladder was associated with the appearance of alkali in the serosal compartment. The mean rate of hydrogen ion secretion in the absence of electrical and concentration gradients across the bladder was $0.96 \mu \mathrm{mole} / \mathrm{hr}$. The secretion rate was only slightly greater in the presence of the spontaneous potential difference. The maximal hydrogen ion gradient that could be generated by the bladder was $3.33 \mathrm{pH}$ units in the presence of the spontaneous voltage and $3.02 \mathrm{pH}$ units in the short-circuited state.

Hydrogen ion secretion was markedly reduced by acetazolamide and anaerobiosis, which indicated that under our experimental conditions acidification depended on the production and enzymatic hydration of metabolic carbon dioxide. On the basis of the stoichiometry of the $\mathrm{pH}$ changes across the membrane under different conditions, it is suggested that the active transport mechanism for hydrogen ion is located near the mucosal surface of the epithelial cell and that the alkali generated in back of the pump moves passively into the serosal fluid along an electrochemical gradient.
\end{abstract}

\section{Introduction}

The urinary bladder of the fresh water turtle shares with the kidney the ability to conserve sodium $(2,3)$ and to acidify the urine (4). Since the functional complexity of the kidney has been

\footnotetext{
* Received for publication 8 February 1967 and in revised form 12 June 1967.

Supported by grants from the William F. Milton Fund of Harvard University, the American Heart Association, and a General Research Support Grant, 5S01 FR05479-04, from the U. S. Public Health Service.

Presented in part before the annual meeting of the American Society for Clinical Investigation, 1 May 1966, Atlantic City, N. J. (1).

$\ddagger$ Recipient, U. S. Public Health Service Career Development Award 7-K3-HE-12-113-03.

Address requests for reprints to Dr. Philip R. Steinmetz, Beth Israel Hospital, 330 Brookline Avenue, Boston, Mass. 02215.
}

a limiting factor in our understanding of hydrogen ion transport in the renal tubules, the isolated turtle bladder was selected for a study of the cellular mechanisms of urine acidification in an in vitro system which would permit control and measurement of electrical and concentration driving forces. By means of a $\mathrm{pH}$ stat technique the rate of hydrogen ion secretion ${ }^{1}$ was measured in a system free from external carbon dioxide and bicarbonate.

The studies indicate that the movement of hydrogen ion cannot be accounted for by electrical forces or concentration gradients across the epithelium but must depend by exclusion on active transport, either by a mechanism of direct coupling

\footnotetext{
1 The term "hydrogen ion secretion" as employed in this paper carries no implications about the nature of charge transfer involved in hydrogen ion transport.
} 
to metabolic energy production or by linkage to the active transport of another ion. The secretion of hydrogen ion into the mucosal solution is associated with alkalinization of the serosal solution. On the basis of the observed characteristics of the secretion of acid and alkali on the two sides of the membrane and the acid-base changes occurring with inhibition of production of metabolic $\mathrm{CO}_{2}$, it is suggested that the active transport mechanism for hydrogen ion is located near

TABLE I

Comparison of hydrogen ion secretion in turtle bladder with and without nullification of the spontaneous electrical potential difference $(P D)$

\begin{tabular}{|c|c|c|c|}
\hline Turtle & PD & $\mathrm{H}^{+}$secretion & $\begin{array}{c}\text { Spontaneous/ } \\
\text { nullified } \\
\mathrm{H}^{+} \text {secretion }\end{array}$ \\
\hline 1 & $\begin{array}{l}m v \\
\mathrm{~N} \\
22\end{array}$ & 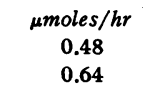 & 1.33 \\
\hline 2 & $\begin{array}{l}44 \\
\mathrm{~N}\end{array}$ & $\begin{array}{l}0.95 \\
0.99\end{array}$ & 0.96 \\
\hline 3 & $\begin{array}{l}\mathrm{N} \\
\mathbf{3 4}\end{array}$ & $\begin{array}{l}0.70 \\
0.95\end{array}$ & 1.36 \\
\hline 4 & $\begin{array}{c}22 \\
N\end{array}$ & $\begin{array}{l}1.83 \\
1.23\end{array}$ & 1.49 \\
\hline 5 & $\begin{array}{l}N \\
34\end{array}$ & $\begin{array}{l}0.80 \\
1.00\end{array}$ & 1.25 \\
\hline 6 & $\begin{array}{l}40 \\
\mathrm{~N}\end{array}$ & $\begin{array}{l}1.66 \\
1.33\end{array}$ & 1.25 \\
\hline 7 & $\begin{array}{l}N \\
13\end{array}$ & $\begin{array}{l}0.93 \\
0.97\end{array}$ & 1.04 \\
\hline 8 & $\begin{array}{l}29 \\
\mathrm{~N} \\
26 \\
\mathrm{~N}\end{array}$ & $\begin{array}{l}1.02 \\
0.78 \\
0.57 \\
0.49\end{array}$ & $\begin{array}{l}1.30 \\
1.16\end{array}$ \\
\hline 9 & $\begin{array}{c}N \\
28 \\
N \\
29\end{array}$ & $\begin{array}{l}0.99 \\
1.23 \\
1.27 \\
1.17\end{array}$ & $\begin{array}{l}1.24 \\
0.92\end{array}$ \\
\hline 10 & $\begin{array}{c}16 \\
\mathrm{~N} \\
32 \\
\mathrm{~N}\end{array}$ & $\begin{array}{l}1.12 \\
0.99 \\
1.28 \\
1.13\end{array}$ & $\begin{array}{l}1.13 \\
1.13\end{array}$ \\
\hline 11 & $\begin{array}{c}\mathrm{N} \\
50 \\
\mathrm{~N} \\
32\end{array}$ & $\begin{array}{l}1.06 \\
1.21 \\
1.28 \\
1.48\end{array}$ & $\begin{array}{l}1.14 \\
1.16\end{array}$ \\
\hline $\begin{array}{l}\text { Mean } \pm \text { SE, periods } \\
\text { with nullified } \\
\text { PD }\end{array}$ & s & $0.96 \pm 0.07$ & \\
\hline $\begin{array}{l}\text { Mean } \pm \text { SE, periods } \\
\text { with spontane- } \\
\text { ous PD }\end{array}$ & $\begin{array}{l}s \\
30 \pm 2.6\end{array}$ & $1.14 \pm 0.09$ & $1.19 \pm 0.04$ \\
\hline
\end{tabular}

Periods with spontaneous PD and nullified (N) PD were alternated in the sequence listed. The mean ratio of $\mathrm{H}^{+}$secretion (spontaneous/ nullified) was greater than 1.00 , the difference being statistically significant $(P<0.01)$. The mean short-circuit current in this group of experiments was $206 \pm 15 \mu a$, or $7.7 \pm 0.6 \mu$ moles/hr of positive charge
from mucosal to serosal (direction opposite that of $\mathrm{H}^{+}$transport) solution. the mucosal surface of the epithelium and that the alkali generated in back of the "hydrogen ion pump" moves passively into the serosal fluid along an electrochemical gradient.

\section{Methods}

Urinary bladders of adult water turtles, Pseudemys scripta elegans, were removed with a minimum of handling, washed with Ringer's solution, and mounted between two halves of a lucite chamber, which provided an exposed membrane area of $8 \mathrm{~cm}^{2}$. The spontaneous electrical potential difference (PD) across the bladder was measured with a Keithley model 200 B voltmeter (Keithley Instruments, Cleveland, Ohio) at 10-min intervals, and the PD was nullified according to Ussing and Zerahn (5) by passage of current from an external voltage clamp circuit (6), which operated automatically and permitted continuous nullification. The two sides of the bladder were bathed with identical Ringer's solution designed to have the following composition: $\mathrm{Na}^{+}, 115.0 \mathrm{mEq} /$ litér $; \mathrm{K}^{+}, 3.5 \mathrm{mEq} /$ liter; $\mathrm{Ca}^{++}$, 0.9 mmole/liter; $\mathrm{Cl}^{-}, 119.7 \mathrm{mEq} /$ liter; $\mathrm{HPO}_{4}=0.3$ mmole/liter; dextrose, $2.0 \mathrm{mmole} / \mathrm{liter}$; osmolality, 228 $\mathrm{mOsm} / \mathrm{kg} \mathrm{H}_{2} \mathrm{O}$. The Ringer's solution was free from $\mathrm{HCO}_{3}^{-}$and the air with which the solutions were stirred was first passed through $3 \mathrm{M} \mathrm{KOH}$ to trap $\mathrm{CO}_{2}$. This bubbling system was effective in removing $\mathrm{CO}_{2}$ from the solutions as demonstrated in the following experiments. In four experiments ${ }^{14} \mathrm{CO}_{2}$ was liberated in a small vessel from $\mathrm{NaH}^{14} \mathrm{CO}_{8}$ by the addition of $\mathrm{HCl}$. 15 $\mathrm{ml}$ of air containing ${ }^{14} \mathrm{CO}_{2}$ gas was bubbled through the Ringer's solution in the chamber over a period of $3 \mathrm{sec}$. Frequent samples were taken immediately after regular bubbling with air began. The half-time of disappearance of counts was less than $2 \mathrm{~min}$. In four other experiments in which trace amounts of $\mathrm{NaH}^{14} \mathrm{CO}_{3}$ were added to the solution the half-time of disappearance varied from 9 to $22 \mathrm{~min}$. In the anaerobic experiments $\mathrm{N}_{2}$ was bubbled through an $\mathrm{O}_{2}$ trap (7) and a $\mathrm{CO}_{2}$ trap in series. During the 1st hr after mounting, the Ringer's solutions were exchanged three times in order to remove contaminant solutes from the bladder. The $\mathrm{pH}$ of the aerated Ringer's solution in the chambers was adjusted to $7.40 \pm$ 0.10. The $\mathrm{pH}$ stat technique, introduced by Durbin and Heinz (8) for the frog stomach, was adapted to the mucosal side of the turtle bladder. A Radiometer $\mathrm{pH}$ meter, titrator, and titrigraph assembly were employed; a combination glass and reference electrode and a delivery burette which contained $0.01 \mathrm{~N} \mathrm{NaOH}$ as titrant, were mounted directly in the upper compartment of the mucosal chamber. The current from the external voltage clamp was applied to the fluid bathing the bladder in the lower compartment and did not affect the $\mathrm{pH}$ reading obtained from the glass electrode in the upper compartment. In one series of experiments the $\mathrm{pH}$ stat assembly was mounted in the serosal chamber and $0.01 \mathrm{~N}$ $\mathrm{HCl}$ was used as the titrant. With the Ringer's solutions employed the $\mathrm{pH}$ state was sensitive to the addition 
of 2.5 nmoles of $\mathrm{H}^{+}$or $\mathrm{OH}^{-}$to $10 \mathrm{ml}$ of bathing solution. Unless otherwise noted the experimental periods were 40 $80 \mathrm{~min}$ in duration. From the volume of titrant delivered and the time interval, the secretion rate, expressed as $\mu$ moles $/ \mathrm{hr}$ per $8 \mathrm{~cm}^{2}$ of membrane area, was calculated.

In the experiments in which the $\mathrm{pH}$ stat assembly was operating on the mucosal side and inhibitors were added to the serosal fluid, a second $\mathrm{pH}$ meter was used to monitor the $\mathrm{pH}$ on the serosal side. The volume of Ringer's solution employed in each half chamber varied from 9 to $11 \mathrm{ml}$.

\section{Results}

Measurement of $\mathrm{H}^{+}$secretion in absence of electrical and concentration gradients. In Table I, 11 experiments are shown in which the $\mathrm{pH}$ stat method was applied to the solution bathing the mucosal surface of the bladder. Hydrogen ion secretion is expressed in $\mu$ moles/hour per $8 \mathrm{~cm}^{2}$ of bladder. The spontaneous electrical potential difference (PD) was oriented so that the mucosal solution was negative with respect to the serosal solution. In each bladder the rate of $\mathrm{H}^{+}$secretion in the presence of the spontaneous PD was compared with the rate during continuous nullification $(\mathrm{N})$ of the PD. Hydrogen ion secretion continued in the absence of an electrical gradient across the bladder. The mean secretion rate in the short-circuited state was only slightly less than that in the presence of the PD, the difference being of borderline significance. If, however, the ratio of the secretion rate in the spontaneously active bladder over the rate in the same bladder in the short-circuited state was calculated for all paired periods, the mean of the ratios was greater than one, the difference being statistically significant.

Maximal $\mathrm{H}^{+}$gradients. The maximal $\mathrm{H}^{+}$gradient that could be generated by the turtle bladder in the presence and absence of the spontaneous $\mathrm{PD}$ is presented in Table II for 10 experiments in which identical Ringer's solutions with an initial $\mathrm{pH}$ of $7.1 \pm 0.1$ were employed on both sides of the bladder. The initial $\mathrm{pH}$ was somewhat lower than that in the $\mathrm{pH}$ stat experiments, since the solutions for the gradient experiments were buffered with $0.1 \mathrm{~mm} \mathrm{Na}_{2} \mathrm{HPO}_{4}$ instead of the usual $0.3 \mathrm{~mm} \mathrm{Na}_{2} \mathrm{HPO}_{4}$. In three of the five experiments carried out in the presence of the spontaneous $\mathrm{PD}$, the $\mathrm{pH}$ gradient generated by the bladder reached maximal values over $3 \mathrm{pH}$ units, the highest value being $3.33 \mathrm{pH}$ units. The last
TABLE II

\begin{tabular}{|c|c|c|c|c|c|}
\hline & \multirow[b]{3}{*}{$\mathrm{PD}$} & & & \multicolumn{2}{|c|}{$\mathrm{pH}$} \\
\hline & & \multicolumn{2}{|c|}{$\mathrm{pH}$} & \multirow{2}{*}{$\begin{array}{l}\text { Maximal } \\
\text { gradient } \\
\text { observed }\end{array}$} & \multirow{2}{*}{$\begin{array}{l}\text { Expected } \\
\text { gradient } \\
\text { from PD }\end{array}$} \\
\hline & & Mucosal & Serosal & & \\
\hline & $m v$ & & & & \\
\hline \multicolumn{6}{|c|}{$\begin{array}{l}\text { Spontaneous } \\
\text { PD }\end{array}$} \\
\hline 1 & 32 & 4.93 & 8.10 & 3.17 & 0.54 \\
\hline 2 & 24 & 5.52 & 7.70 & 2.18 & 0.41 \\
\hline 3 & 62 & 4.95 & 8.28 & 3.33 & 1.05 \\
\hline 4 & 28 & 4.94 & 7.58 & 2.64 & 0.47 \\
\hline 5 & 36 & 4.62 & 7.95 & 3.33 & 0.61 \\
\hline \multicolumn{6}{|c|}{$\begin{array}{l}\text { Short- } \\
\text { circuited }\end{array}$} \\
\hline 6 & $\mathrm{~N}$ & 5.91 & 8.27 & 2.36 & 0 \\
\hline 7 & $\mathrm{~N}$ & 4.88 & 7.90 & 3.02 & $\mathbf{0}$ \\
\hline 8 & $\mathrm{~N}$ & 5.38 & 7.32 & 1.94 & 0 \\
\hline 9 & $\mathrm{~N}$ & 5.09 & 7.89 & 2.80 & 0 \\
\hline 10 & $\mathrm{~N}$ & 5.10 & 7.72 & 2.62 & 0 \\
\hline
\end{tabular}

N, PD nullified.

column indicates the $\mathrm{pH}$ gradient that could have been expected on the basis of the electrical PD alone. It is clear that the observed gradients are many times greater than the expected values.

The maximal $\mathrm{H}^{+}$gradients in the short-circuited state are almost as great as those observed in the presence of the $\mathrm{PD}$, the highest value being 3.02 $\mathrm{pH}$ units. In two of the experiments carried out in the short-circuited state the maximal gradient increased slightly $(0.30 \mathrm{pH}$ units in turtle 7 and $0.22 \mathrm{pH}$ units in turtle 9) when the spontaneous $\mathrm{PD}$ was restored. The time required to reach the maximal $\mathrm{pH}$ gradient varied from 4 to $7 \mathrm{hr}$.

In all of these experiments the observed change in $\mathrm{pH}$ was considerably greater on the mucosal side than on the serosal side of the epithelium. The mucosal $\mathrm{pH}$ fell from an initial value of 7.1 to final values close to 5.0 , whereas the serosal $\mathrm{pH}$ rose less than $1 \mathrm{pH}$ unit in most experiments. The importance of this discrepancy for locating the site of $\mathrm{H}^{+}$transport will be considered later. After the maximal $\mathrm{H}^{+}$gradient was reached, both the mucosal and serosal $\mathrm{pH}$ decreased somewhat over the next several hours (from 0.1 to $0.2 \mathrm{pH}$ units over a $2 \mathrm{hr}$ period) without significant change in the maximal $\mathrm{pH}$ gradient.

Comparison of acid secretion in mucosal fluid with alkali secretion in serosal fluid. Since acidification of mucosal fluid was associated with alkalinization of the serosal fluid, the $\mathrm{pH}$ stat technique could also be applied to the serosal compartment 
TABLE III

Comparison of secretion of acid on mucosal side with secretion of alkali on serosal side of bladder

\begin{tabular}{cccc}
\hline \hline & $\begin{array}{c}\mathrm{H}^{+} \text {secre- } \\
\text { tion, } \\
\text { mucosal } \\
\text { fluid }\end{array}$ & $\begin{array}{c}\text { OH- secre- } \\
\text { tion, } \\
\text { serosal } \\
\text { fluid }\end{array}$ & $\begin{array}{c}\text { Difference, } \\
\mathrm{H}^{+}-\mathrm{OH}^{-}\end{array}$ \\
\hline & & $\mu$ moles $/ \mathrm{hr}$ & \\
1 & 1.45 & 1.22 & 0.23 \\
2 & 0.77 & 0.87 & -0.10 \\
3 & 0.93 & 0.70 & 0.23 \\
4 & 0.42 & 0.33 & 0.09 \\
5 & 1.67 & 1.28 & 0.39 \\
6 & 0.69 & 0.64 & 0.05 \\
7 & 0.88 & 0.60 & 0.28 \\
Mean & 0.97 & 0.81 & 0.17 \\
ISE & & & \pm 0.06 \\
\hline
\end{tabular}

In turtles $1,3,5$, and 7 the $\mathrm{pH}$ stat was first applied to the serosal side with $0.01 \mathrm{~N} \mathrm{HCl}$ as titrant and, thereafter, to the mucosal side by means of $0.01 \mathrm{~N} \mathrm{NaOH}$. In turtles 2,4 , and 6 the sequence was reversed. The mean value $\left(\mathrm{H}^{+}-\mathrm{OH}^{-}\right)$was significantly different from $0(P<0.05)$.

after the titrant was changed from $0.01 \mathrm{~N} \mathrm{NaOH}$ to $0.01 \mathrm{~N} \mathrm{HCl}$. In Table III, $\mathrm{H}^{+}$secretion on the mucosal side is compared with alkali secretion on the serosal side in the same bladder. Although the two rates were of similar magnitude, $\mathrm{H}^{+}$secretion exceeded $\mathrm{OH}^{-}$secretion in six of the seven experiments; the mean difference was $0.17 \mu$ mole/ $\mathrm{hr}$ and was significantly different from $0(P<$ 0.05). These comparisons were made under steady-state aerobic conditions. The stoichiometry of $\mathrm{H}^{+}$and $\mathrm{OH}^{-}$secretion is markedly affected, as will be shown later, by changes in oxidative metabolism.
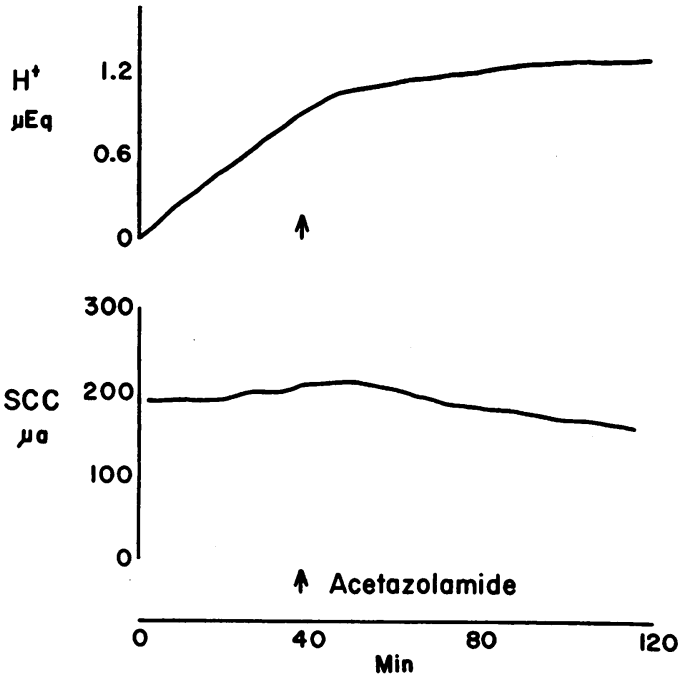

Fig. 1. Effect of acetazolamide on cumulative $\mathrm{H}^{+}$SECRETION AND ON THE SHORT-CIRCUIT CURRENT (SCC).
Except for the experiments of Table III, all $\mathrm{H}^{+}$ secretion rates were measured directly by the $\mathrm{pH}$ stat technique on the mucosal side. In order to examine the possibility that $\mathrm{pH}$ changes resulted from transport of buffer anion or leakage of a buffer from the epithelial cell layer, we made comparisons of the buffer capacity of fresh Ringer's solution and Ringer's solution removed from the mucosal side of the bladder at the end of $\mathrm{pH}$ stat experiments that lasted from 3 to $6 \mathrm{hr}$. In 11 such comparisons in which the solutions were titrated from $\mathrm{pH} 7.4$ to 4.4 there were no systematic differences in buffer capacity; in six of these comparisons in which the titrations were extended to $\mathrm{pH} 2.5$ there was a mean increase in buffer capacity of $12 \pm 6 \%$ (SEM). These increases were small since the total buffer content of the initial mucosal fluid consisted of only $3 \mu$ moles $\mathrm{Na}_{2} \mathrm{HPO}_{4}$, whereas the values for total $\mathrm{H}^{+}$transport were often greater than $6 \mu$ moles. These results indicate that there was no significant transport of $\mathrm{HPO}_{4}=$, the buffer anion of our solutions, and that the small quantities of buffer with low $\mathrm{pK}$ added to the mucosal fluid made an insignificant contribution to acid secretion.

Dependence of $\mathrm{H}^{+}$secretion on the enzymatic hydration of metabolic $\mathrm{CO}_{2}$ and on oxidative metabolism. Since the rate of bubbling could be shown to influence the $\mathrm{pH}$ of the bathing solutions in the presence of $\mathrm{HCO}_{3}^{-}$or $\mathrm{CO}_{2}$, a nonvolatile buffer system was employed in all $\mathrm{pH}$ stat experiments. The Ringer's solutions were free from $\mathrm{HCO}_{3}{ }^{-}$and the air was passed through a $\mathrm{CO}_{2}$ trap. Although the observed $\mathrm{H}^{+}$secretion did not

TABLE IV

Effect of acetazolamide on rate of $\mathrm{H}^{+}$secretion and shortcircuit current (SCC)

\begin{tabular}{|c|c|c|c|c|}
\hline \multirow[t]{3}{*}{ Turtle } & \multicolumn{2}{|c|}{$\mathrm{H}^{+}$secretion } & \multicolumn{2}{|c|}{ SCC } \\
\hline & \multicolumn{2}{|c|}{ 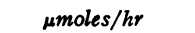 } & \multicolumn{2}{|c|}{$\mu a$} \\
\hline & $C^{*}$ & A & C & $\mathbf{A}$ \\
\hline 1 & 1.10 & 0.21 & 253 & 230 \\
\hline 2 & 0.92 & 0.05 & 115 & 100 \\
\hline 3 & 1.30 & 0 & 230 & 250 \\
\hline 4 & 1.12 & 0.20 & 200 & 184 \\
\hline 5 & 0.90 & 0 & 160 & 186 \\
\hline 6 & 1.17 & 0.18 & 155 & 147 \\
\hline 7 & 1.11 & 0.26 & 172 & 192 \\
\hline Mean & 1.09 & 0.13 & 183 & 184 \\
\hline$\pm \mathrm{SE}$ & \pm 0.05 & \pm 0.04 & \pm 18 & \pm 19 \\
\hline
\end{tabular}

* C, control; A, acetazolamide added to serosal fluid in a concentra tion of 0.2-0.6 mmole/liter. All measurements were made in the shortcircuited state. 


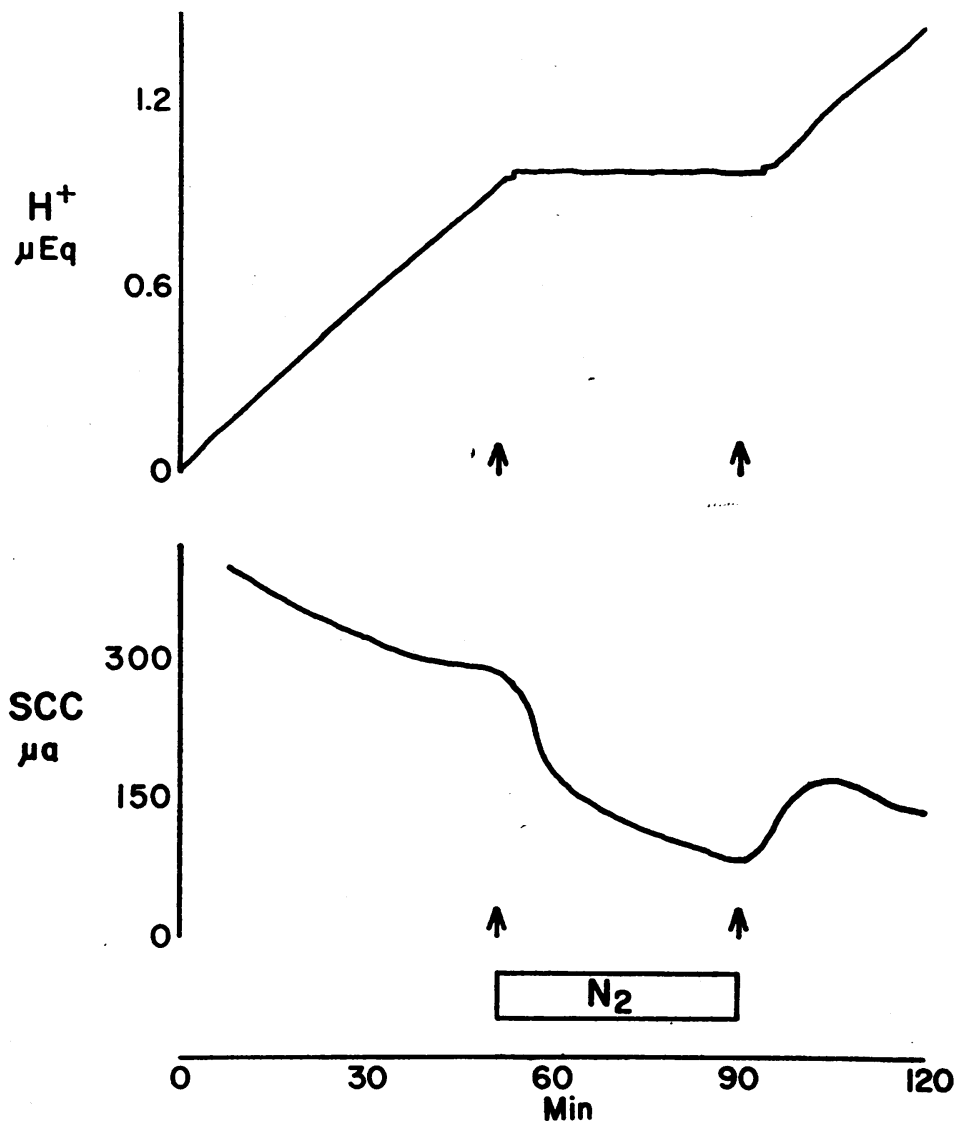

Fig. 2. Effect of Deoxygenation with $\mathrm{N}_{2}$ on cumulative $\mathrm{H}^{+}$SECRETION AND ON THE SHORT-CIRCUIT CURRENT (SCC). At $90 \mathrm{~min}$, air bubbling was resumed.

require exogenous $\mathrm{CO}_{2}$ and $\mathrm{HCO}_{3}$ in the bathing media, the possibility that it was dependent on the metabolic production of $\mathrm{CO}_{2}$ and its subsequent hydration within the cell was examined in experiments in which either carbonic anhydrase activity or oxidative metabolism was inhibited.

In Fig. 1, an experiment is shown in which acetazolamide was added to the serosal fluid. Cumulative $\mathrm{H}^{+}$secretion, as recorded by the titrigraph, is shown in the upper frame. The slope of the curve representing the rate of $\mathrm{H}^{+}$secretion. decreased markedly after acetazolamide administration. The short-circuit current (SCC) changed little.

In Table IV the results of seven experiments on the effects of acetazolamide are shown. $\mathrm{H}^{+}$secretion was markedly reduced in five and abolished in two of the experiments; no consistent changes in the SCC were observed.
The results of two kinds of experiments designed to interfere with oxidative metabolism and $\mathrm{CO}_{2}$ formation are shown in Table V.

Removal of $\mathrm{O}_{2}$ from the system by replacement of air with $\mathrm{N}_{2}$ virtually abolished $\mathrm{H}^{+}$secretion in 5 of 10 experiments. One of these experiments is

TABLE V

Effects of anaerobiosis and exposure to sodium cyanide on $\mathrm{H}^{+}$ secretion and short-circuit current (SCC)

\begin{tabular}{lcr}
\hline & $\mathrm{H}^{+}$secretion & \multicolumn{1}{c}{$\mathrm{SCC}$} \\
\hline & $\mu$ moles $/ h r$ & $\mu a$ \\
Control & $0.95 \pm 0.06$ & $240 \pm 38$ \\
$\mathrm{~N}_{2}$ & $0.20 \pm 0.09$ & $72 \pm 11$ \\
Control $^{*}$ & $1.03 \pm 0.14$ & $227 \pm 54$ \\
NaCN $^{*}$ & $0.48 \pm 0.08$ & $36 \pm 13$ \\
\hline
\end{tabular}

* Mean values and SE are presented for $10 \mathrm{~N}_{2}$ experiments and 7 experiments in which $\mathrm{NaCN}$ was added to the serosal fluid in a concentration of $2 \times 10^{-3} \mathrm{~mole} / \mathrm{liter}$. 
shown in Fig. 2. In the five remaining experiments $\mathrm{H}^{+}$secretion continued at a very low rate. The SCC decreased markedly in all experiments.

Administration of $\mathrm{NaCN}$ in a concentration of $2 \times 10^{-3}$ mole/liter to the serosal solution caused a consistent decrease in $\mathrm{H}^{+}$secretion to a mean value slightly less than half the initial rate in seven experiments. $\mathrm{H}^{+}$secretion was not completely abolished in any of the $\mathrm{NaCN}$ experiments, although the effect on the SCC was at least as great as that due to $\mathrm{N}_{2}$. Addition of fresh $\mathrm{NaCN}$ to the serosal solution or to both bathing solutions caused no additional changes in $\mathrm{SCC}$ or $\mathrm{H}^{+}$ secretion.

In all eight experiments in which the serosal $\mathrm{pH}$ was monitored, deoxygenation with $\mathrm{N}_{2}$ resulted in an increase in the $\mathrm{pH}$ of the serosal solution of from 0.15 to $0.25 \mathrm{pH}$ units. This increase occurred gradually over a period of $20 \mathrm{~min}$ after the change from air to $\mathrm{N}_{2}$ and was reversible over a similar period of time if air was reinstituted. Since $\mathrm{N}_{2}$ and air were bubbled through the same alkali trap and the Ringer's solutions had the same
$\mathrm{pH}$ when bubbled with either gas, the transient alkalinization of the serosal compartment was attributed to an efflux of alkali from the cell after the inhibition of metabolic $\mathrm{CO}_{2}$ formation. The $\mathrm{pH}$ of the mucosal solution remained at the $\mathrm{pH}$ stat level. In Fig. 3 (lower frame) a diagram is given of the $\mathrm{H}^{+}$and alkali shifts that occur in the serosal compartment in a typical experiment. The changes indicated in the upper frame were obtained in a different experiment carried out on the mucosal side of the bladder. In this experiment the inhibitory effect of $\mathrm{N}_{2}$ on $\mathrm{H}^{+}$secretion into mucosal fluid was representative of the results presented in Table V.

Since $\mathrm{NaCN}$ and acetazolamide are alkaline and require titration with $\mathrm{HCl}$ at the time of administration, it is hazardous to assign $\mathrm{pH}$ changes caused by these substances to a resulting inhibition of the production or the hydration of $\mathrm{CO}_{2}$.

\section{Discussion}

These results confirm the observation by Schilb and Brodsky (4) that the urinary bladder
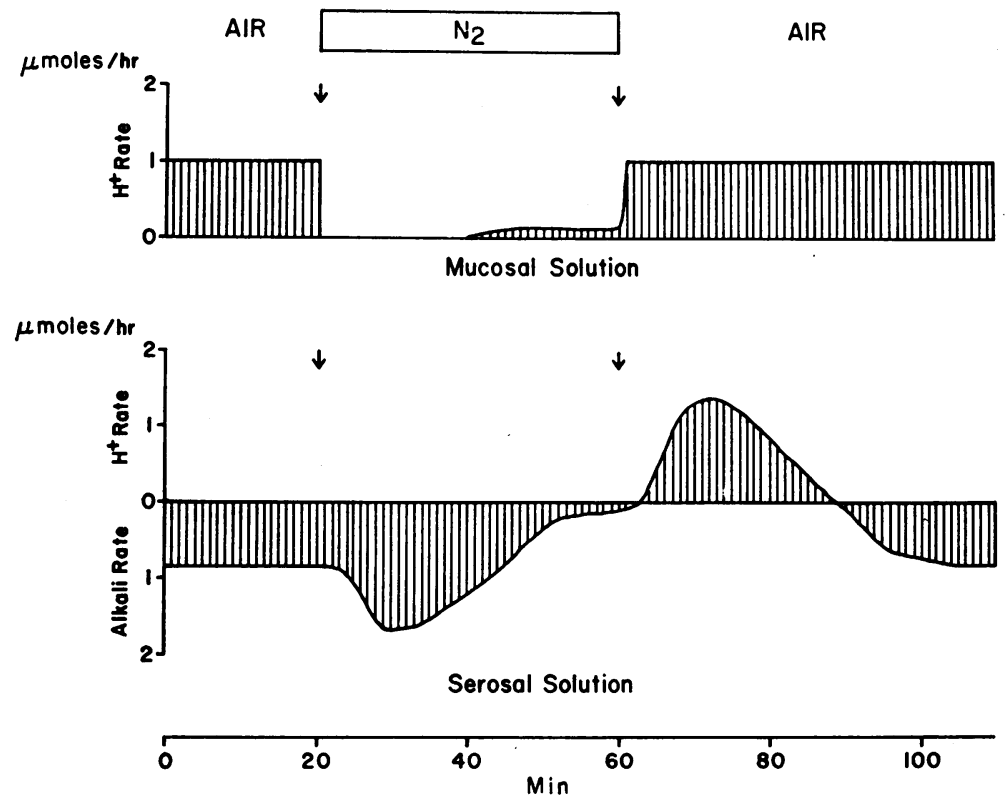

Fig. 3. Diagram of the EFFECT OF ANAERobIosis on ACID-BASE SHIFTS IN THE SEROSAL COMPARTMENT AND ON $\mathrm{H}^{+}$SECRETION INTO THE MUCOSAL COMPARTMENT. In the experiment in which the serosal acid-base changes were measured, the titrant was changed from $0.01 \mathrm{~N} \mathrm{HCl}$ to $0.01 \mathrm{~N} \mathrm{NaOH}$ at the beginning of reoxygenation to cover the period of acidification. The rates of $\mathrm{H}^{+}$secretion into the mucosal compartment were obtained from a separate experiment, the results of which closely resembled the mean results presented for $10 \mathrm{~N}_{2}$ experiments in Table V. 
of the water turtle is capable of acidifying the mucosal medium. Under our experimental conditions, however, the mechanism of acidification appears to differ from that proposed by these investigators. Schilb and Brodsky (4) suggest, on the basis of studies in a bladder sac preparation, that acidification of the mucosal fluid occurs by a mechanism of transcellular transport of $\mathrm{HCO}_{3}{ }^{-}$in the ionic form from the mucosal to the serosal side of the epithelium. In their experiments the free $\mathrm{CO}_{2}$ concentration was observed to be lower in the mucosal solution within the sac than in the serosal solution. The presence of this gradient for $\mathrm{CO}_{2}$ was interpreted as indicating that acidification of the mucosal fluid had occurred by removal of $\mathrm{HCO}_{3}{ }^{-}$rather than by the addition of $\mathrm{H}^{+}$, and, furthermore, that $\mathrm{CO}_{2}$ was not freely diffusible across the bladder wall.

In our studies acidification did not depend on the presence of $\mathrm{HCO}_{3}{ }^{-}$in the bulk solutions or on the transport of $\mathrm{HPO}_{4}=$ across the bladder. The simplest explanation for our results would be that $\mathrm{H}^{+}$ions generated by the epithelium are added to the mucosal solution and that the $\mathrm{OH}^{-}$ions dissociated within the epithelial cells appear in the serosal solution in the form of some basic anion. Although the system was free of exogenous $\mathrm{CO}_{2}$ and $\mathrm{HCO}_{3}^{-}$, metabolic $\mathrm{CO}_{2}$ was being produced in all aerobic experiments. It is likely, therefore, that at least part of the alkali appearing in the serosal solution was $\mathrm{HCO}_{3}{ }^{-}$that was formed within the epithelial cells. Alternatively, it is possible that some metabolic $\mathrm{CO}_{2}$ that diffused into the mucosal solution was hydroxylated to $\mathrm{HCO}_{3}{ }^{-}$in the unstirred fluid layer at the mucosal membrane and that $\mathrm{HCO}_{3}^{-}$so formed was transported transcellularly in the manner suggested by Schilb and Brodsky (4). However, the rapidity with which $\mathrm{CO}_{2}$ is removed from the bulk solutions by the bubbling system and the fact that the bladder was mounted as a thin membrane (with a degree of stretch comparable to that of a maximally distended bladder in vivo) make it unlikely that sufficient $\mathrm{HCO}_{3}{ }^{-}$would be available in such a boundary layer to account for the observed acidification. For the present, the over-all process of acidification will be referred to as $\mathrm{H}^{+}$secretion. When we discuss the individual steps of the process at the two surfaces of the epithelial cell layer we will return to the role of $\mathrm{HCO}_{3}{ }^{-}$transport.
Since $\mathrm{H}^{+}$secretion takes place in the absence of concentration or electrical potential gradients across the bladder epithelium, it fulfills the accepted criteria for an active transport mechanism. Hence, it must be coupled either directly to metabolic energy production or to the active transport of another ion such as $\mathrm{Na}^{+}$or $\mathrm{Cl}^{-}$, a possibility examined in the following article (9).

The rate of $\mathrm{H}^{+}$secretion, as measured by the $\mathrm{pH}$ stat method, was little influenced by nullification of th spontaneous electrical PD across the bladder. Although the "normal" negativity of the mucosal solution provides an electrical driving force for the movement of $\mathrm{H}^{+}$into the mucosal solution, the mean secretion rate in the short-circuited state was so close to that in the spontaneously active state that comparisons had to be made in the same bladders before a significant contribution of the electrical-driving force to the rate of secretion could be demonstrated. The minor role played by electrical forces across the epithelium was also evident in the observations on the maximal $\mathrm{H}^{+}$gradient that could be generated by the isolated bladder. The gradients reached in the short-circuited state were almost as great as in the presence of the spontaneous electrical PD, the largest gradients observed being 3.02 and 3.33 $\mathrm{pH}$ units, respectively.

What is the role of metabolic production of $\mathrm{CO}_{2}$ and lactic acid in the mechanism of $\mathrm{H}^{+}$secretion? The observed dependence of acidification on the production and enzymatic hydration of $\mathrm{CO}_{2}$ within the cells appears to indicate that the base generated in association with $\mathrm{H}^{+}$secretion exists mainly in the form of $\mathrm{HCO}_{3}{ }^{-}$. A smaller fraction may exist in the form of lactate. Klahr and Bricker (10) reported that lactate formed by the turtle bladder appears asymmetrically in the bathing solutions, the amounts appearing in the serosal solution being about five times as great as those in the mucosal solution. Similar observations have been made in the frog stomach, which has a mechanism for $\mathrm{H}^{+}$secretion, and in the toad bladder, which has no such mechanism $(11,12)$. The mean total rate of lactate formation in the turtle bladder preparation of Klahr and Bricker was $0.16 \mu$ mole $/ \mathrm{hr}$ per $7 \mathrm{~cm}^{2}$ of bladder, a value considerably smaller than our rate of $\mathrm{H}^{+}$secretion of about $1 \mu \mathrm{mole} / \mathrm{hr}$ per $8 \mathrm{~cm}^{2}$ of bladder. In fact, the difference observed in our studies be- 
tween the rates of secretion of $\mathrm{H}^{+}$and alkali on the two sides of the epithelium has about the magnitude of the rate of lactate formation indicated above. Furthermore, it is of interest that anaerobiosis, which is known to increase lactate formation (10), reduces $\mathrm{H}^{+}$secretion.

Since urine acidification is not directly dependent on the active transport of $\mathrm{Na}^{+}$or $\mathrm{Cl}^{-}$(1, 9 ), there must be an active transport mechanism for either $\mathrm{H}^{+}$or alkali. Since a pump for one generates the other, these alternatives are best examined in relation to the location of the transport mechanism in the epithelium. If it is assumed that acidification requires only one active transport mechanism, the active step could be located either at the serosal membrane of the epithelial cell layer or at the mucosal membrane. According to the first possibility, the pump at the serosal surface of the cell would transport alkali into the serosal fluid and generate $\mathrm{H}^{+}$ions within the cell; the $\mathrm{H}^{+}$ ions would move passively along an electrochemical gradient into the mucosal fluid. Several of our results make this possibility very unlikely. In order to account for the maximal $\mathrm{pH}$ gradient observed in the short-circuited state by passive forces, the intracellular $\mathrm{pH}$ would have to be below 5.0, or the cell interior would have to be electrically positive relative to mucosal fluid by more than $150 \mathrm{mv}$. No direct information is available on the electrical profile or the intracellular $\mathrm{pH}$ in the turtle bladder, yet certain inferences may be

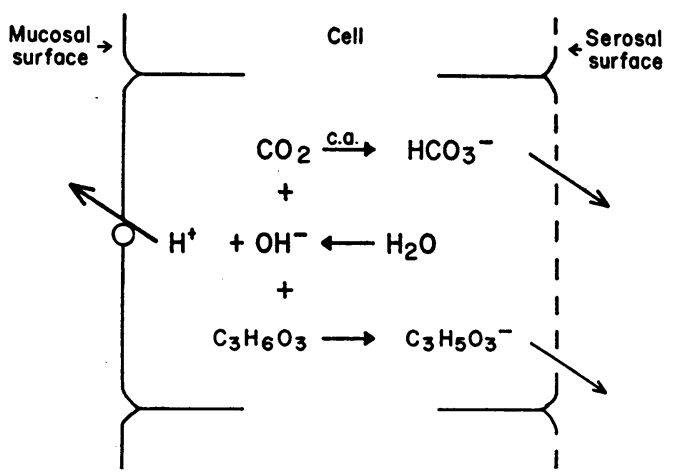

Fig. 4. MOdel FOR THE MEChANISM OF $\mathrm{H}^{+}$SECRETION in EPITHELIUM of tURTLE BLAdDER. The $\mathrm{H}^{+}$pump is located at the mucosal surface of the cell. $\mathrm{OH}^{-}$ions left behind in the cell are neutralized by the enzymatic hydroxylation of metabolic $\mathrm{CO}_{2}$ and to a small extent by reaction with lactic acid. $\mathrm{HCO}_{3}^{-}$and $\mathrm{C}_{3} \mathrm{H}_{5} \mathrm{O}_{3}^{-}$move passively into the serosal compartment along an electrochemical gradient. c.a., carbonic anhydrase. made from studies of other epithelia. In the short-circuited state the cell interior of frog skin and toad bladder is slightly negative to the outside of the cell (13-15). Estimation of the intracellular $\mathrm{pH}$ by the dimethyl-oxazolidinedione (DMO) method in the isolated renal tubule of the dog (16) and in the epithelium of the toad bladder (17) has yielded values in a relatively alkaline range. The epithelium of the turtle bladder would have to be very different from these other tissues to provide passive forces for the movement of $\mathrm{H}^{+}$from cytoplasm to mucosal fluid.

Another argument against the existence of an active transport mechanism for alkali at the serosal surface of the epithelium depends upon the acidbase changes during deoxygenation. It is indeed unlikely that the efflux of alkali into the serosal compartment during the initial period of exposure to $\mathrm{N}_{2}$ would represent acceleration of an active transport mechanism. These changes are more likely a reflection of the acute acid-base changes that occur within the cells as a result of the disappearance of metabolic $\mathrm{CO}_{2}{ }^{2}$ and are consistent with the second alternative, namely that acid-base changes across the serosal surface are determined by passive forces and, hence, that the active transport step is located at the mucosal membrane.

A pump at the mucosal membrane could either transport $\mathrm{H}^{+}$ions into the mucosal fluid or alkali into the cell. In the presence of $\mathrm{HCO}_{3}{ }^{-}$on the mucosal side of the membrane the pump might operate by transporting $\mathrm{HCO}_{3}^{-}$into the cell interior according to the model of Schilb and Brodsky (4). Under our experimental conditions, however, any $\mathrm{HCO}_{3}{ }^{-}$in the mucosal boundary layer should have been formed from metabolic $\mathrm{CO}_{2}$ diffusing across the mucosal surface of the epithelium. It is unlikely that there would be sufficient $\mathrm{HCO}_{3}$ - in the unstirred layer to account for the observed acidification, especially since the mucosal membrane should be relatively impermeable to $\mathrm{H}^{+}, \mathrm{HCO}_{3}^{-}$, and $\mathrm{CO}_{2}$ to permit the operation of an effective transport system. A model consistent with our experimental results is presented in Fig. 4. $\mathrm{H}^{+}$ions are transported actively

2 Although organic acid production increases during anaerobiosis, we assume that in our preparation in the absence of exogenous $\mathrm{CO}_{2}$ the sudden decrease in endogenous $\mathrm{CO}_{2}$ production causes a rise in $\mathrm{pH}$, which transiently outweighs the effect of increased organic acid production. 
across the relatively impermeable mucosal surface of the epithelial layer; the $\mathrm{OH}^{-}$ions generated within the cells react with $\mathrm{CO}_{2}$ and lactic acid to form $\mathrm{HCO}_{3}{ }^{-}$and lactate, and these ions move along an electrochemical gradient into the serosal compartment. The concentration gradient would favor this movement and in the spontaneously active bladder there would be an additional electrical driving force in this direction. This model provides an explanation for the observed deviations from a "one for one" stoichiometry in the rates of secretion on the two sides of the membrane. Organic acids, such as lactic acid, neutralize a fraction of the $\mathrm{OH}^{-}$generated in back of the $\mathrm{H}^{+}$pump. Organic acid formation would also account for the tendency of the $\mathrm{pH}$ to fall on both sides of the epithelium after the maximal $\mathrm{H}^{+}$gradient had been reached; such acid production would lower the $\mathrm{pH}$ in the cell and contiguous serosal compartment and thereby would lift the gradient limitation on $\mathrm{H}^{+}$secretion into the mucosal fluid. If the important $\mathrm{pH}$ barrier is located at the mucosal surface of the epithelium, $\mathrm{H}^{+}$ions secreted into the mucosal fluid are buffered only by the Ringer's solution, whereas the $\mathrm{OH}^{-}$ions are buffered in the cell as well as in the serosal fluid; hence, an explanation would be provided for the greater $\mathrm{pH}$ changes in the mucosal fluid in the gradient experiments shown in Table II.

The role of the enzymatic hydroxylation of $\mathrm{CO}_{2}$ and the inhibitory effect of acetazolamide in this model are comparable to the mechanism suggested by Davies (18) for $\mathrm{H}^{+}$secretion by the oxyntic cells of the stomach. He indicated that the secretion of $\mathrm{H}^{+}$is dependent on the continuous removal of $\mathrm{OH}^{-}$by the hydroxylation of $\mathrm{CO}_{2}$ and, with Roughton (18, appendix to reference), presented calculations demonstrating that carbonic anhydrase is required to obtain a sufficiently rapid rate of hydroxylation to permit neutralization of alkali within the cell.

Recently Struyvenberg, Morrison, and Relman (16) demonstrated in the isolated renal tubule of the dog that the intracellular $\mathrm{pH}$, as estimated by the DMO method, increased after exposure to acetazolamide, an observation consistent with the view that the disposal of $\mathrm{OH}^{-}$in the cell requires the catalyzed hydroxylation of $\mathrm{CO}_{2}$. In our system, in which the availability of $\mathrm{CO}_{2}$ was limited to metabolic $\mathrm{CO}_{2}$, carbonic anhydrase appeared to play an important role in permitting hydroxylation of a sufficient fraction of the available $\mathrm{CO}_{2}$. On the other hand, Schilb and Brodsky (4) reported that acidification continued in their preparation in the presence of acetazolamide. A possible explanation for this difference is provided by the fact that their preparation was maintained in an environment of $5 \% \mathrm{CO}_{2}$, the high concentration of which made relatively less important the role of enzymatic hydroxylation.

Although reduced or absent $\mathrm{CO}_{2}$ production may explain the inhibition of $\mathrm{H}^{+}$secretion after exposure to $\mathrm{NaCN}$ or $\mathrm{N}_{2}$, it is possible that these measures, in addition, interfere with the supply of energy to the transport mechanism. Attempts to examine this possibility by making exogenous $\mathrm{CO}_{2}$ available in the presence of $\mathrm{N}_{2}$ were complicated by the need to employ a volatile buffer system that made the $\mathrm{pH}$ stat results poorly reproducible at low secretion rates.

The persistence of low rates of $\mathrm{H}^{+}$secretion after exposure to $\mathrm{NaCN}$ and in some experiments after exposure to $\mathrm{N}_{2}$ suggests that acid production from anaerobic metabolism may play a role in $\mathrm{H}^{+}$ secretion. The rate of $\mathrm{H}^{+}$secretion, however, was somewhat greater and more predictable in the $\mathrm{NaCN}$ experiments than in the $\mathrm{N}_{2}$ experiments. The possibility is, therefore, raised that a " $\mathrm{NaCN}$ insensitive" oxidative pathway of glycolytic metabolism contributes to $\mathrm{H}^{+}$secretion either by $\mathrm{CO}_{2}$ production or by providing energy to the $\mathrm{H}^{+}$ pump. These questions remain open and the precise mechanism of coupling between the transport of $\mathrm{H}^{+}$and the metabolic production of energy remains to be clarified.

\section{Acknowledgment}

We are grateful to Miss Joyce Stichman and Mrs. Edith Delbrouck for technical assistance.

\section{References}

1. Steinmetz, P. R., and H. S. Frazier. 1966. Char acteristics of hydrogen ion transport in urinary bladder of the turtle. J. Clin. Invest. 45: 1077. (Abstr.)

2. Klahr, S., and N. S. Bricker. 1964. Na transport by isolated turtle bladder during anaerobiosis and exposure to KCN, Am. J. Physiol. 206: 1333. 
3. Brodsky, W. A., and T. P. Schilb. 1966. Ionic mechanisms for sodium and chloride transport across turtle bladders. Am. J. Physiol. 210: 987.

4. Schilb, T. P., and W. A. Brodsky. 1966. Acidification of mucosal fluid by transport of bicarbonate ion in turtle bladders. Am. J. Physiol. 210: 997.

5. Ussing, H. H., and K. Zerahn. 1951. Active transport of sodium as the source of electric current in the short-circuited isolated frog skin. Acta Physiol. Scand. 23: 110.

6. Menninger, J. R., F. M. Snell, and R. A. Spangler. 1960. Voltage clamp for biological investigations. Rev. Sci. Instr. 31 : 519.

7. Umbreit, W. W., R. H. Burris, and J. F. Stauffer. 1957. Manometric techniques. Burgess Publishing Co., Minneapolis. 3rd edition.

8. Durbin, R. P., and E. Heinz. 1958. Electromotive chloride transport and gastric acid secretion in the frog. J. Gen. Physiol. $41: 1035$.

9. Steinmetz, P. R., R. Omachi, and H. S. Frazier. 1967. Independence of hydrogen ion secretion and transport of other electrolytes in turtle bladder. J. Clin. Invest. $46: 1541$.

10. Klahr, S., and N. S. Bricker. 1965. Energetics of anaerobic sodium transport by the fresh water turtle. J. Gen. Physiol. 48: 571.
11. Hogben, C. A. M. 1962. Ultrastructure and transport across epithelial membranes. Circulation. 26 : 1179.

12. Leaf, A. 1959. The mechanism of the asymmetrical distribution of endogenous lactate about the isolated toad bladder. J. Cellular Comp. Physiol. 54 : 103.

13. Engbaek, L., and T. Hoshiko. 1957. Electrical potential gradients through frog skin. Acta Physiol. Scand. 39 : 348.

14. Scheer, B. T., and M. W. Mumbach. 1960. The locus of the electromotive force in frog skin. $J$. Cellular Comp. Physiol. 55 : 259.

15. Frazier, H. S. 1962. The electrical potential profile of the isolated toad bladder. J. Gen. Physiol. 45 : 515.

16. Struyvenberg, A., R. B. I. Morrison, and A. S. Relman. 1966. The acid-base behavior of separated renal tubules. J. Clin. Invest. 45 : 1077. (Abstr.)

17. Leaf, A., A. Keller, and E. F. Dempsey. 1964. Stimulation of sodium transport in toad bladder by acidification of mucosal medium. Am. J. Physiol. 207 : 547.

18. Davies, R. E. 1948. Hydrochloric acid production by isolated gastric mucosa. Biochem. J. $42: 609$.

\section{NOTICE TO SUBSCRIBERS}

Post Offices will not forward the Journal when you move.

Please notify The Journal of Clinical Investigation, The Rockefeller University Press, Box 261, New York, N. Y. 10021, when your address changes. Include your zip code number. 